degree by 1940 . The following two years were spent working in the Law Library at the University of Michigan, while she completed the requirements for a degree in library science.

After three years as an attorney for the National Labor Relations Board in Washington, and following a special assignment in which she served as an attorney-advisor on international law aspects of war crimes for the Civil Affairs Division of the U.S. Army, Kate Wallach returned to law libraries as Assistant Librarian at the University of North Carolina. In 1949 she was appointed Law Librarian at L.S.U., where she remained until her retirement.

Kate Wallach's background in both common law and civil law systems, combined with an ability to work in at least five languages, led her to develop a library collection at L.S.U. that is unusually rich in foreign and comparative materials. She was the author of more than forty publications, including the standard manual for research in Louisiana law, as well as the compiler of a union list of Latin American legal materials. She was an authority on the French and Spanish sources of Louisiana law.

Prominent within her profession, Kate Wallach served as President of both the American Association of Law Libraries (1966-1967) and the Louisiana Library Association (1960-1961). She held the position of Professor of Law at L.S.U. from 1964, regularly offering a variety of seminars in comparative law. In 1970 she relinquished her administrative responsibilities, but remained as Comparative Law Librarian until her retirement in 1975 .

On her retirement Dean Paul M. Hebert remarked, "As library administrator, law teacher, scholar, comparatavist, as devoted friend to a generation of students, and as a national leader among law librarians, Kate Wallach has made contributions to legal education in general and to the development of Louisiana law in particular that can never be erased." To this may properly be added her dedication to the international aspects of legal scholarship. She is remembered as a dear and distinguished colleague by her friends in many countries.

LANCE E. Dickson

Librarian and Professor

Louisiana State University Law Center

\title{
Jurij Fedynskyj (1912-1979): In Memoriam
}

Dr. Jurij Fedynskyj, the recently retired Associate Librarian and Associate Professor of Law at Indiana University in Bloomington, died November 25, 1979 at the age of 67. He died of cancer after a long illness, with a regret that fate did not allow him enough time to write the 
memoirs of what he himself described as a rather long and very interesting life.

Jurij Fedynskyj was born on September 19, 1912 in Western Ukraine. He graduated from the University of Lviv in 1934 and was admitted to the practice of law. Between the time of his birth and his becoming assistant professor of law at Lviv University (1939-41) the jurisdiction of his native land changed from Austro-Hungary to Poland and then to the USSR. He left his country during the war and continued to study law at the universities of Vienna and Innsbruck. He received his doctorate from Innsbruck in 1943. Having immigrated to the United States, he earned a Master's degree in library science from Columbia in 1957 and then in 1965 his JD from Indiana. Fedynskyj's career as a law librarian began at Notre Dame University; from 1959 on he was associated with Indiana. A former Secretary of the International Association of Law Libraries, he was also an active member of American Association of Law Libraries, of American Foreign Law Association, of American Association of Comparative Study of Law and other professional organizations. He served on the editorial board of the American Journal of Comparative Law. Fedynskyj participated also in the life of the Ukrainian emigré community: a full member of Shevchenko Scientific Society, he was a contributor to the Ukrainian Encyclopedia and headed for a couple of terms the Ukrainian-American Association of University Professors.

Though Fedynskyj taught courses in comparative and international law, he spent the final two decades of his life primarily as a law librarian. $\mathrm{He}$ would have much preferred to be able to devote all of his time to scholarship. His one and only book, Rechtstatsachen auf dem Gebiete des Erbrechts in Gerichtsbezirk Innsbruck (Innsbruck: Universitätsverlag Wagner, 1968) grew out of his doctoral dissertation, but was published a quarter of a century later. The well known Austrian scholar Franz Gschnitzer described it as an unusual inquiry into the field of fact research in law and as the only such study available for the law of inheritance. Another Austrian reviewer (E.M. Bajons) felt that Fedynskyj succeeded in combining the material of his empirical social research with a dogmatic judicial insight. A similar sociological approach was used by Fedynskyj in his 1953 article "Sovietization of an occupied area through the medium of the courts" where his conclusions about the role of civil law in the process of gradual "Sovietization" are based on an analysis of a file of cases which came for appellate review before a Soviet provincial court in Northern Bukovina. Fedynskyj also wrote on topics from legal history and bibliography. The titles of his articles testify to the breadth of his interests: "State session laws in non-English languages", "Western legal treatises in Russian translation", "Prominent Polish legal scholars of the last one hundred years". His last published piece, as far as I know, was the paper on "Legal documentation and research", co-authored with John H. Crabb, presented as one of American contributions at the 10th International Congress of Comparative Law in Budapest in 1978. 
Though Dr. Fedynskyj and I trace our origins to the same area in Eastern Europe, and though we knew each other by name from the Ukrainian emigré press, we met for the first time at the AALL convention in Philadelphia in 1968. Even afterwards our personal contacts were limited to AALL meetings, but they were considerably enriched by a delightful AALL sponsored post-convention trip to Mexico in 1969 as well as by personal correspondence. Dr. Fedynskyj impressed me as an intellectually stimulating companion, a man of considerable personal charm, a European gentleman-of a slightly old-fashioned rare variety. $\mathrm{He}$ accepted his fate's verdict with dignified quiet resignation. In a letter written eight months before his death he recalled several instances from his past where he was spared-as if miraculously-in life-threatening situations. Describing stoically his final losing struggle, he said: "I have used up my allotment of miracles."

Dr. Fedynskyj is survived by his wife, Dr. Natalia Fedynskyj, a son and a daughter, two grandsons and two brothers.

Marta Tarnawsky

University of Pennsylvania 